\title{
Mobile-Based Application: The Designation of Energy Saving Smart Light System for Monitoring and Controlling
}

\author{
https://doi.org/10.3991/ijim.v15i18.24733
}

\author{
Zirawani Baharum ${ }^{1(\bowtie)}$, Azim Saiful Sabudin ${ }^{1}$, Ernie Mazuin Mohd Yusof ${ }^{1}$, \\ Nahdatul Akma Ahmad ${ }^{2}$ \\ ${ }^{1}$ Universiti Kuala Lumpur, Johor Bahru, Malaysia \\ ${ }^{2}$ Universiti Selangor, Selangor, Malaysia \\ zirawani@unikl.edu.my
}

\begin{abstract}
Therefore, this prototype also using motion sensor to sense movement to increase the light brightness. Light is the basis of all life on our planet, anytime and everywhere. Curving of demands, the alternative sources are important to explore and investigate in order to increase the satisfaction on user necessity. However, researcher also need to looking forward to find an alternative ways to optimise the usage of light as well. Therefore, this research provides the ideas of the prototype on the implementation of the smart lamp with controlled light system based on Arduino and mobile application usage to save the energy. To minimize and preserve light with the remote system in order to monitor and control the brightness of light, the smart lamp is chosen. This research is conducted to design the energy saving smart light system via mobile application and devices for monitoring and controlling. A minor prototype is developed with fully automated and controlled by Arduino board. It is begin with recognition of input of LDR sensor, PIR sensor arranging and circuit establishing. Later, the incorporation of hardware and software is implemented via Arduino program, mobile application and the devices. Finally, the testing process is executed and the data is assembled and analysed. Generally, the system has been empirically validated with several situation as setting up devices. The light with this kind of method always accurately matched to the human needs that allocates to save on the energy usage and minimise thecosts, as well as to improve the human comfort and efficiency.
\end{abstract}

Keywords—smart lamp, arduino, mobile apps, LED, sensor

\section{Introduction}

Today's trend, human kind always bring smartphone everywhere. Electricity consumption is increasing every year because of the demand of users. Commonly 
electricity use is in lighting system, audio system, daily routine and other things. Mostly usage of electricity consumption is lighting system because with light people can do a job or task easily when at day night or dark area. Energy is the foundation that supports and spurs the socio-economic development of a country. Development is not possible without energy and sustainable development is not possible without sustainable sources of energy. Consumption of vitality of light increase every year in Malaysia, hence to entire world. In Malaysia, statistics shown the usage of electricity increased between five to six per cent every year due to rapid growth in industrial fields [1]-[3]. The use of energy also contributes form several sectors consist of agriculture, residential, commercial, industrial and transport.

Malaysia has developed new healthy generating capacity and adds increase 4780 megawatt. Figure 1 shows the final energy consumption and final usage of electricity consumption that increase every year. In 1971, the electricity consumption was 3,464 GWH and in 2008 the electricity increasing to 94,728 GWH. Besides that, in year 2020 demand in Malaysia electricity consumption will increase around $30 \%$, which mean it is 124,677 GWH [4]-[6].

As the lighting system is important, the purpose of this project is to design smart lighting system that can control light brightness with LDR (Light Dependent Resistor) sensor and occupancy sensor such as PIR (Passive Infrared) sensor. By design smart light that controlled by light intensity sensor by surrounding area, it also can be monitor and control by mobile application. Furthermore, the prototype has dual mode is that are automatic and manual mode to ease user.

\section{$2 \quad$ Literature review}

Nowadays, a usage of energy consumption increased every year due to human demand and needs. Electricity usage is very important for human kind to do their work and daily routine. In recent decades, saving energy has become a vital issue in many countries. The energy awareness and energy conservation has started to open up new avenue in saving energy area [7]. Lighting is one of the major uses of electricity and accounts for major portion of national electricity usage for instance building lighting system consumes about half of total energy usage of building [8]-[10]. It means that diminishing the consumed energy by lighting system is sufficient to decrease the expenses and $\mathrm{CO} 2$ emission. 


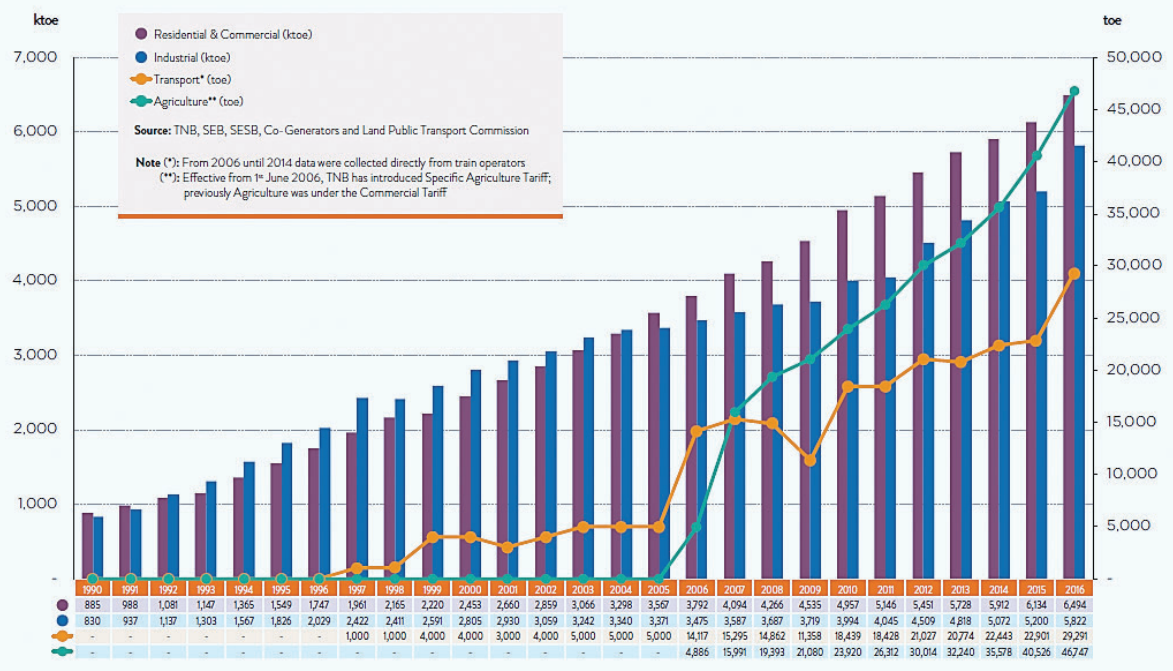

Fig. 1. Final electricity consumption by sector

Basically, the lighting system used manual switch that is on-off switch. Sometimes people forget to switch off the light and the electricity usage is wastage due to life style habits and working environment. On and off switch lighting system will make losing the focus on the work because they need to stand and walk to switch on the light to continue they work [11],[12]. Although, people habits nowadays is lethargic to switch on the light until they feel hard to continue do work. Thus, the aim for this project is to design smart light that the brightness of light is controlled by light intensity in the area. After that, this project also developed personal control from mobile device controlling and monitoring the lamp and light. Moreover, the prototype has dual mode is that are automatic and manual mode to ease user. Table 1 shows the summarisation on several research project that have been done by several researcher from year 2013 to 2016 to obtain general knowledge on method used within that years.

Meanwhile, Table 1 shows the method used to construct the smart light system from several researchers. Before proceed with this method several understanding must be considered to ensure the process of development efficient and excellent such as light concepts, the control system (PUC, PIR, LDR), comparison between LED, Incandescent bulbs and CFLs [13]. This summary of each method is used in the direction for this research development as well. Every project has different way of process system. As a result, the suitable method is using Arduino based smart light control system [14],[15],[18] and it is suitable to depict for this project. This method is selected due to effortless in the code development and cost effective. Moreover, the project execution is also easy to be deployed and conducted with Arduino software program [19],[20]. 
Table 1. Summarization of method approach for lighting control system

\begin{tabular}{|c|c|c|c|c|c|c|}
\hline Research Title & Authors & Year & Sector & Motivation & Solution & Result \\
\hline $\begin{array}{l}\text { Arduino Based: } \\
\text { Smart Light } \\
\text { Control System }\end{array}$ & $\begin{array}{l}\text { Deepak } \\
\text { Kumar Rath } \\
{[14]}\end{array}$ & 2016 & Resident & $\begin{array}{l}\text { Wastage of } \\
\text { electricity }\end{array}$ & $\begin{array}{l}\text { Use LDR to } \\
\text { control light } \\
\text { power }\end{array}$ & $\begin{array}{l}\text { Reduce the } \\
\text { cost of bill }\end{array}$ \\
\hline $\begin{array}{l}\text { Zigbee Based } \\
\text { Smart Street } \\
\text { Light Control } \\
\text { System Using } \\
\text { LabVIEW }\end{array}$ & $\begin{array}{l}\text { Manish } \\
\text { Kumar, } \\
\text { Ravinder } \\
\text { Kumar } \\
\text { and Ritula } \\
\text { Thakur [16] }\end{array}$ & 2016 & $\begin{array}{l}\text { Walkway } \\
\text { and street }\end{array}$ & $\begin{array}{l}\text { Low } \\
\text { frequency } \\
\text { usage. Power } \\
\text { waste. }\end{array}$ & $\begin{array}{l}\text { Use Zigbee + } \\
\text { LabVIEW } \\
\text { to monitor } \\
\text { and manage } \\
\text { wirelessly }\end{array}$ & $\begin{array}{l}\text { Eliminate } \\
\text { traffics, } \\
\text { reduce cost } \\
\text { and time } \\
\text { maintenance }\end{array}$ \\
\hline $\begin{array}{l}\text { Smart Lighting } \\
\text { System using } \\
\text { Raspberry PI }\end{array}$ & $\begin{array}{l}\text { Ankit } \\
\text { Maslekar [11] }\end{array}$ & 2015 & Resident & $\begin{array}{l}\text { Reduce } \\
\text { carbon } \\
\text { emissions }\end{array}$ & $\begin{array}{l}\text { Using webcam } \\
\text { to control the } \\
\text { system }\end{array}$ & $\begin{array}{l}\text { Help to } \\
\text { reduce } \\
\text { consumption } \\
\text { bill }\end{array}$ \\
\hline $\begin{array}{l}\text { ZigBee Remote } \\
\text { Control } \\
\text { Automatic } \\
\text { Street Light }\end{array}$ & $\begin{array}{l}\text { Srikanth M } \\
{[15]}\end{array}$ & 2014 & Street light & $\begin{array}{l}\text { Waste energy } \\
\text { consumption }\end{array}$ & $\begin{array}{l}\text { Use Zigbee } \\
\text { module to } \\
\text { monitor and } \\
\text { control the } \\
\text { light at base } \\
\text { station }\end{array}$ & $\begin{array}{l}\text { Provide safe } \\
\text { night time } \\
\text { environment }\end{array}$ \\
\hline $\begin{array}{l}\text { Zigbee-based } \\
\text { intelligent street } \\
\text { lighting system. }\end{array}$ & $\begin{array}{l}\text { Sagar Prakash } \\
\text { Deo, Asha } \\
\text { Sachin Patil } \\
{[17]}\end{array}$ & 2014 & Street light & $\begin{array}{l}\text { To reduce } \\
\text { the human } \\
\text { error in the } \\
\text { operation }\end{array}$ & $\begin{array}{l}\text { A novel scheme } \\
\text { for a Zigbee- } \\
\text { based street } \\
\text { light control }\end{array}$ & $\begin{array}{l}\text { Decrease } \\
\text { the energy } \\
\text { consumption } \\
\text { and ease the } \\
\text { maintenance }\end{array}$ \\
\hline $\begin{array}{l}\text { Light Control } \\
\text { System Based } \\
\text { on Wireless } \\
\text { Communication } \\
\text { and LED } \\
\text { Technology }\end{array}$ & $\begin{array}{l}\text { Pilar Elejoste, } \\
\text { Ignacio A, } \\
\text { Asier P, Aitor } \\
\text { C, Ignacio J } \\
\text { G Z [18] }\end{array}$ & 2013 & Street light & $\begin{array}{l}\text { High energy } \\
\text { usage in } \\
\text { Spain }\end{array}$ & $\begin{array}{l}\text { Wireless } \\
\text { communication } \\
\text { and devices + } \\
\text { LED } \\
\text { technology } \\
\text { (Sensor) }\end{array}$ & $\begin{array}{l}\text { Ease of } \\
\text { deployment } \\
\text { and } \\
\text { accessibility }\end{array}$ \\
\hline
\end{tabular}

Table 2. Method to construct the smart light system

\begin{tabular}{|l|l|l|l|}
\hline \multicolumn{1}{|c|}{ Method } & \multicolumn{1}{|c|}{ Description } & \multicolumn{1}{|c|}{ Source } \\
\hline $\begin{array}{l}\text { Light } \\
\text { control } \\
\begin{array}{l}\text { System via } \\
\text { Arduino }\end{array}\end{array}$ & $\begin{array}{l}\text { The main circuit using a LDR for } \\
\text { sensing element, which the process of } \\
\text { system by Arduino that take the LDR } \\
\text { sensor as an input element. For output } \\
\text { from Arduino is LED. Other component } \\
\text { such as relay, transistors used for high } \\
\text { voltage supply }\end{array}$ & $\begin{array}{l}\text { Deepak } \\
\text { Kumar Rath, } \\
{[14]}\end{array}$ \\
& & & \\
\hline
\end{tabular}

(Continued) 
Table 2. Method to construct the smart light system (continued)

\begin{tabular}{|c|c|c|c|}
\hline Method & Description & Source & Illustration \\
\hline $\begin{array}{l}\text { Smart } \\
\text { Lighting } \\
\text { System } \\
\text { using } \\
\text { Raspberry } \\
\text { PI }\end{array}$ & $\begin{array}{l}\text { Raspberry PI can generated conserved } \\
\text { energy in electrical grid. The system } \\
\text { hardware and software can modify for } \\
\text { the addition of new module. This system } \\
\text { suitable to implement in industrial, } \\
\text { residential, shop and university to save } \\
\text { energy and reduce cost of consumables } \\
\text { and carbon emission. } \\
\text { The system is use version Linux that } \\
\text { cause the low powered device. Python } \\
\text { language is use for program the circuit } \\
\text { board. This system also use a web } \\
\text { camera to capture image of the room and } \\
\text { compare the image with human pattern } \\
\text { that have save in openCV software. } \\
\text { When the image fails match it will turn } \\
\text { off the power supply. Furthermore, this } \\
\text { system no use occupancy sensor for } \\
\text { operation raspberry PI. }\end{array}$ & $\begin{array}{l}\text { Ankit } \\
\text { Maslekar, [11] }\end{array}$ & wisnar \\
\hline $\begin{array}{l}\text { ZigBee } \\
\text { Remote } \\
\text { Control } \\
\text { Automatic } \\
\text { Street } \\
\text { Light }\end{array}$ & $\begin{array}{l}\text { Arduino as microcontroller and Zigbee } \\
\text { module as based remote control. The } \\
\text { sensor is to control and secure the area } \\
\text { of system. Furthermore, the sensor is the } \\
\text { input and collects the data the transfer to } \\
\text { the controller of the software to analyze } \\
\text { the data to the system. For the Arduino } \\
\text { is to collecting data from all streetlight } \\
\text { in parallel processing and convert the } \\
\text { data into serial communication. Then, } \\
\text { the data will direct transfer to Zigbee } \\
\text { transmitter and receiver modules. When } \\
\text { data sent through ZigBee module, it will } \\
\text { control terminal to check the condition } \\
\text { of the street light. If the condition } \\
\text { of street light is fail, the receiver will } \\
\text { transmit information state of street } \\
\text { light to a terminal }\end{array}$ & $\begin{array}{l}\text { Srikanth M \& } \\
\text { Sudakhar K. } \\
\text { N., [15] }\end{array}$ & 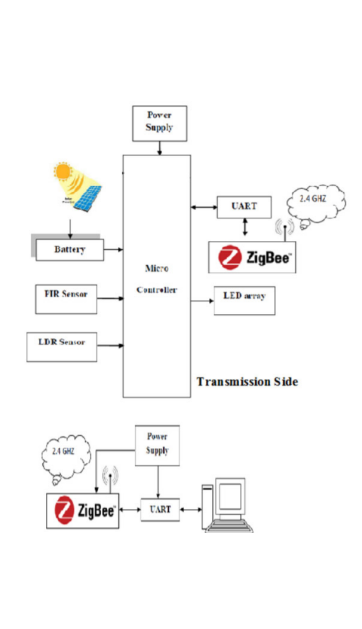 \\
\hline $\begin{array}{l}\text { Remote- } \\
\text { Control } \\
\text { System } \\
\text { (High } \\
\text { Efficiency) } \\
\text { +AI } \\
\text { Intelligent } \\
\text { by a } \\
\text { ZigBee } \\
\text { Network } \\
\text { Devices } \\
\text { and } \\
\text { Sensors }\end{array}$ & $\begin{array}{l}\text { In our project Street lights are made } \\
\text { smart by placing motion sensors on } \\
\text { them, which enables them to detect } \\
\text { movement. Zigbee technology enables } \\
\text { the street lights to communicate with } \\
\text { one another. When a passer-by is } \\
\text { detected by a motion sensor, it will } \\
\text { communicate this to neighbouring } \\
\text { street lights, which will brighten so } \\
\text { that people are always surrounded by } \\
\text { a safe circle of light. Software will } \\
\text { be designed in LabVIEW with which } \\
\text { the street lights can be monitored } \\
\text { and managed wirelessly }\end{array}$ & $\begin{array}{l}\text { Leccese, } \\
\text { Fabio, [19] }\end{array}$ & 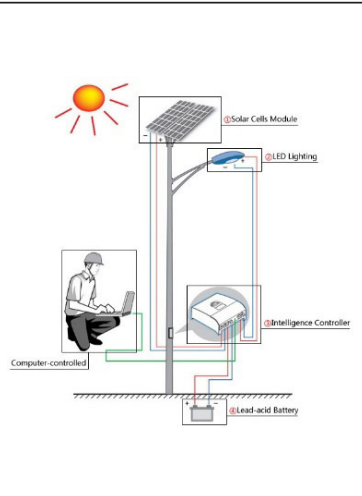 \\
\hline
\end{tabular}




\section{The methodology}

This research is executed through several process and activities. Figure 2 shows the flow process for this research development form beginning to the end. All the process also consider he approach used in this methodology as discussed in Zirawani et al. [13] for the details process flow for the smart lighting system with the consideration of use Arduino microcontroller are Arduino Uno R3, PIR sensor, LDR sensor, Personal control: smartphone and $\mathrm{HC}-05$ Bluetooth. The hardware chosen are integrate into software selected, LabVIEW Interface for Arduino to suit with this research.

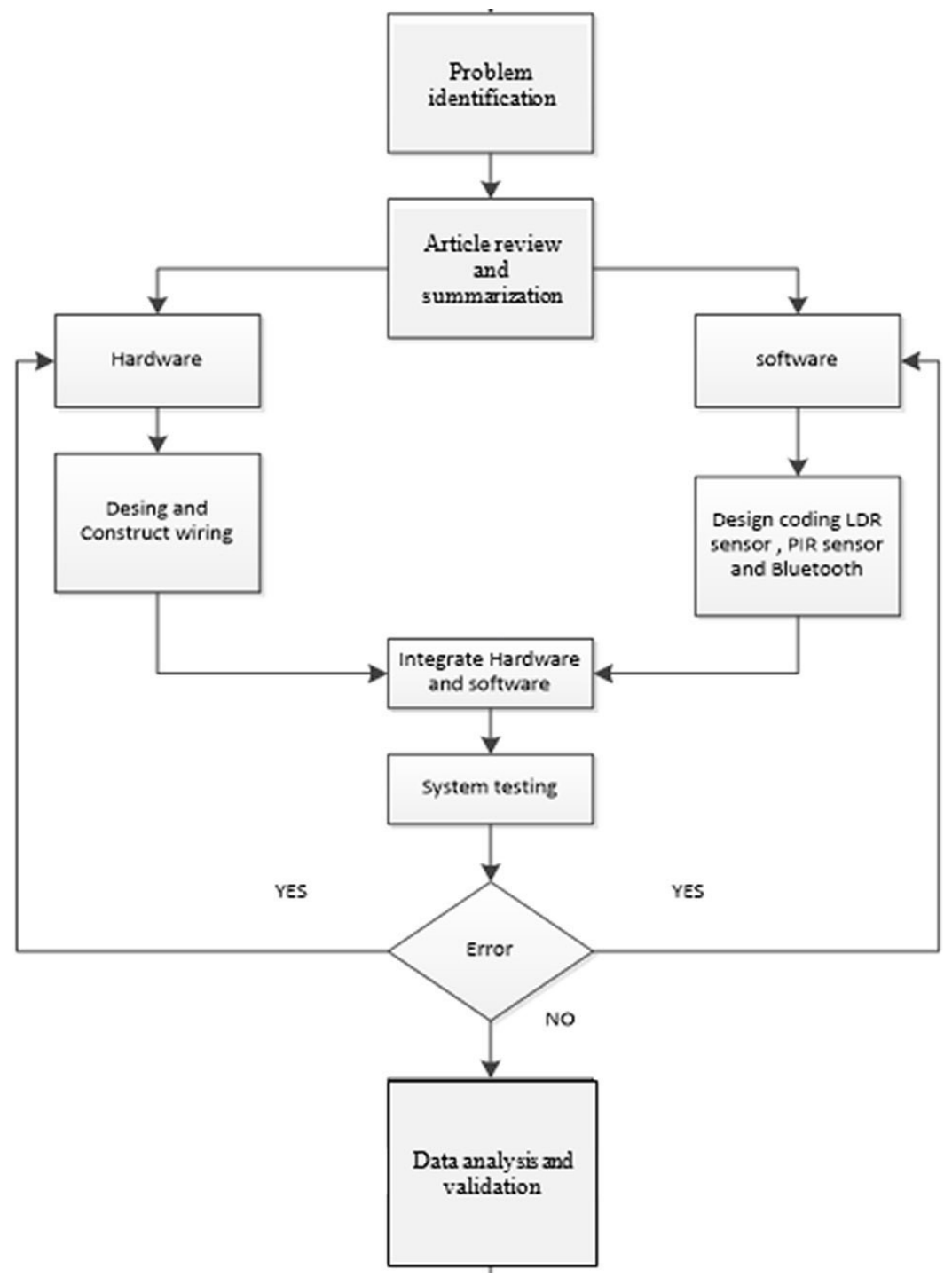

Fig. 2. Process flow for research development 


\section{$4 \quad$ Results and discussion}

The result from this project is when running the system, the LDR sensor able to sense the light intensity in surrounding area. Besides that, LDR sensor should able to convert the signal and send it to Arduino to turn on/off the light bulb. Moreover, the PIR sensor must be able to function properly to sense movement of human. Although, HC-05 Bluetooth module should able to be connected to android smartphone for become remote control to control light manually. The application for interface should function properly for avoids from error the system. This project is to Control the LED brightness using intensity surrounding order to save the electric consumption in the building.

There are three main processes that need to be focused in this project which are the controlling, monitoring and maintaining. The objective of this project is to control the intensity inside the building in order to maintain the LED brightness. Apart from that, in this project, control LED brightness is important because in can reduce electricity consumption by using LDR sensor. The working principle of this project is, when supply voltage to Arduino, the coding will run follow the condition that has been setup. The LDR sensor will read the intensity surrounding. After that, when intensity reach 1000 lux it will switch off the LED because the condition is morning. The PIR sensor is use to sense movement surrounding. When PIR sensor sense movement it will switch on LED will full brightness. After three minutes no movement the PIR sensor sense so LED bulb will dim. Besides that, when toggle button switch to on, the system will go to Bluetooth mode. The smart LED system can be control and monitor the brightness in the mobile apps. If the toggle switch condition is off, the system will back to automatic dimmable led coding.

\subsection{Hardware setup}

The hardware wiring is an important aspect to make sure the prototype run perfectly. Each wire must connect properly to make sure the signal of the input and output sufficiently reach to the electronic component. If the signals fail to function with the component, the circuit will become an open loop and give no feedback to the component. As in Figure 3 shows the prototype schematic circuit diagram of the prototype. Every connection must follow data sheet of components itself in term to avoid any error and circuit trip. In Addition, inside the circuit diagram, this project using an N-Channel MOSFET metal-oxide-semiconductor field-effect transistor for controlling high-power devices from your Arduino, but they do have some limitations. This current configuration is only useful for switching DC current, so don't try this with an AC source, also MOSFETS have both a voltage and an amperage/current limitation. The IRF540 can handle switching up to $60 \mathrm{~V}$ as the amperage is limit to $30 \mathrm{~A}$. 


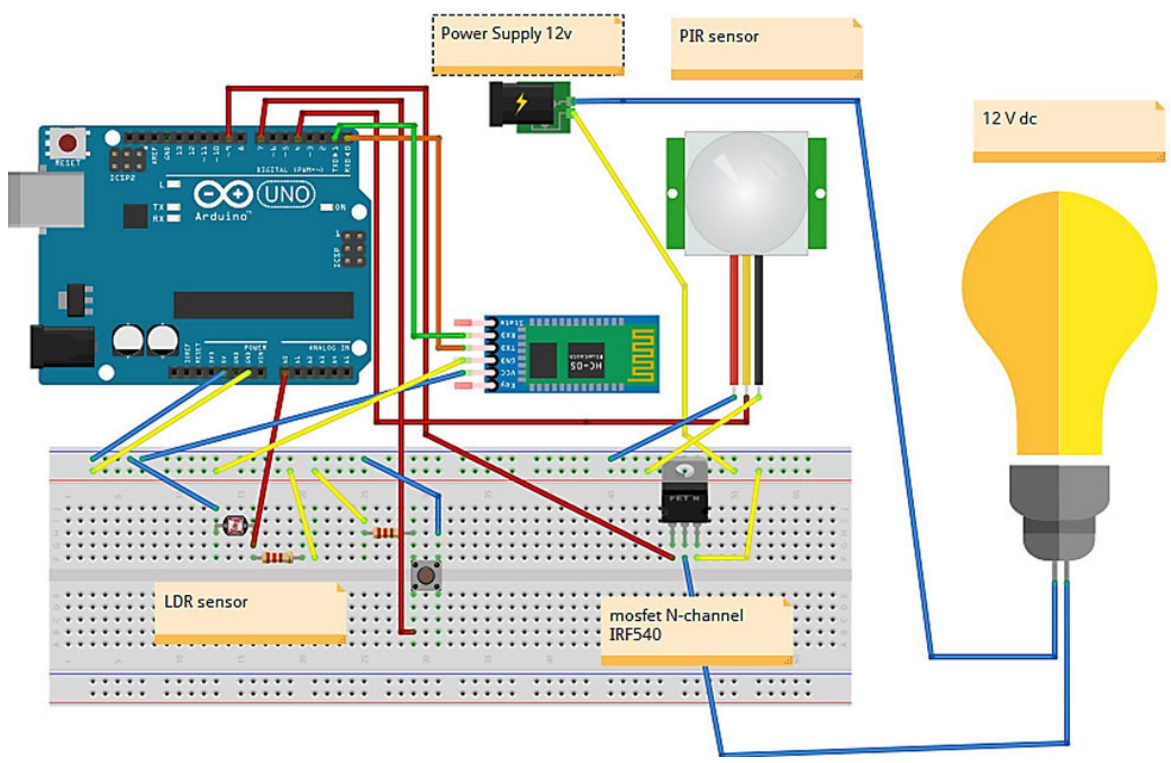

Fig. 3. The wiring of smart light

\subsection{Control system}

Auto-mode. The main process is to control the brightness of LED bulb. This LED bulb can be dimmable which decrease is or increase brightness from $0 \%$ to $100 \%$. LDR sensor used to control the brightness by reading the intensity surrounding. The intensity reading value from analog read will be convert to PWN which is from 0 to 255 because the value will generate a steady square wave of the specified duty cycle to control the brightness. Apart from that, Bluetooth system is added to connect with the smartphone in order to control the LED brightness that interfaced by MIT App Invertor. From there, the system can be used to control the intensity value, LED brightness and voltage out from LED bulb in the serial monitor. Figure 4 shows the serial monitor results through this research. The system automatic read the analog read from LDR sensor and will control the voltage to adjust the brightness for LED lamp. The analog read value for LDR sensor is 0 to 1023 which is has been 2 class of range that is from 0-150 will be night and for 151 above will be sunlight. When daylight the intensity will reach to 1000 lux and the system will switch off the LED. Besides that, the voltage in the serial monitor shows how much voltage out that use from LED bulb according to the LED brightness. So when the intensity increase the voltage out from LED will decrease and when intensity decrease the voltage out from LED will be increase. While the sense movement appears in the serial monitor it show the PIR sensor sense movement in surrounding. Then LED will increase brightness to $100 \%$ instant to show that have nearby people in the area. The voltage will show max voltage 
that LED usage. Though, PIR sensor sense no movement in 3 minutes, the system automatic sent command that motion stop and the automatic smart LED system will run as usual.

Manual-mode. Application design interface using Android mobile devices as remote control is shown in Figure 5. The apps is used to control manually by mobile's user to set the brightness of LED lamp. Plus, Bluetooth module HC-05 also been used to attach the Arduino program and the smartphone apps. When the Bluetooth has been connecting, it will appear label connected in the smartphone interface. After that, press push button on the prototype and the Bluetooth and apps can be used to control the LED brightness. MIT apps for smartphone is examined as well in order to control the smart LED system implementation. This apps will utilize to ensure the ease of control in the way to implement this system using fingers. To run this mode, user need to press push button for switch the system to the Bluetooth mode.
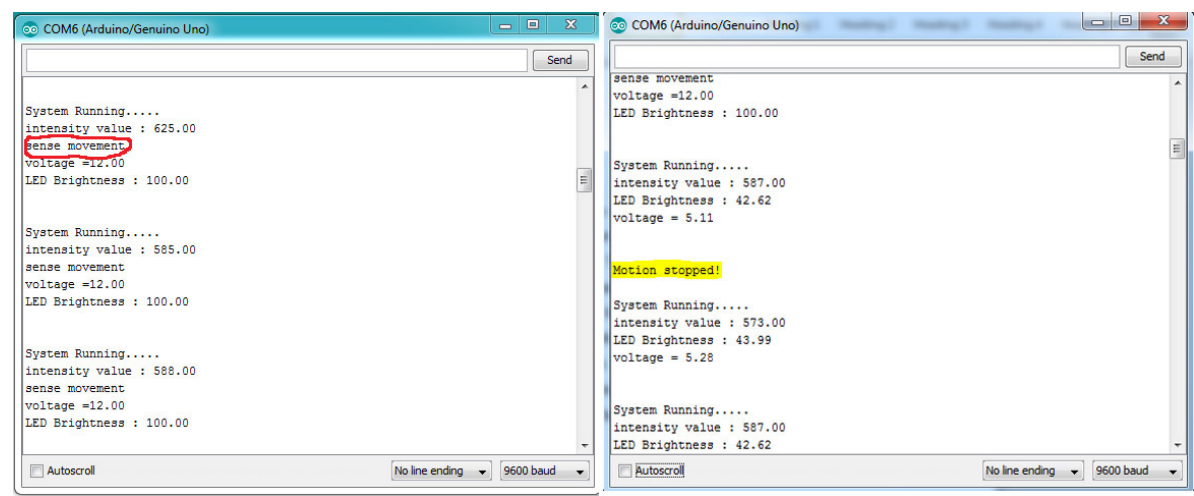

Fig. 4. The serial monitor for smart LED while sense movement and stop movement

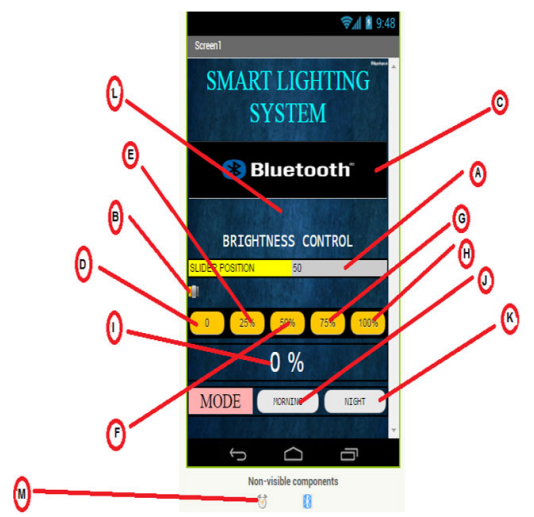

\begin{tabular}{|c|l|l|}
\hline Code & COMMAND & \multicolumn{1}{l|}{ CONDITION } \\
\hline A. & Bluetooth & Connect with HC-05 \\
\hline B. & Slider Brightness & $\begin{array}{l}\text { Adjust LED brightness } \\
\text { Show value PWN O to } 255\end{array}$ \\
\hline C. & Label box & Give O byte number to Arduino \\
\hline D. & 'O\%' & Give 63 byte number to Arduino \\
\hline E. & '25\%' & Give 127 byte number to Arduino \\
\hline F. & '50\%' & Give 191 byte number to Arduino \\
\hline G. & '75\%' & Give 255 byte number to Arduino \\
\hline H. & '100\%' & Show value brightness in percent \\
\hline I. & Label Box & LED off \\
\hline J. & 'Morning' & LED on \\
\hline K & 'Night' & Show Bluetooth connection \\
\hline L. & 'Label box' & $\begin{array}{l}\text { Set intervals and perform time } \\
\text { calculations, manipulations, and } \\
\text { conversions. }\end{array}$ \\
\hline M. & Clock & \\
\hline & &
\end{tabular}

Fig. 5. The smart light system interface design in smartphone with the code condition 


\subsection{Monitoring system}

LabVIEW interface. Figure 6 shows the graphical user interface (GUI) that design and developed through the LabVIEW monitoring Smart light software. To run this GUI, need to setup com port for Arduino to interface with LabVIEW. After that, will upload the LIFA base coding into Arduino so the LabVIEW can interface with Arduino perfectly. From the GUI, the result for voltage usage from LED bulb showed and measured through their intensity with adjacent indicator using LDR sensor. The LDR sensor is connect at pin A0 in Arduino and varies in magnitude in direct proportion to the input light intensity on it. The greater the intensity of light, the greater the corresponding voltage from the LDR will be calculated and resulted. For label box analog pin will show the $\mathrm{A} 0$ follow the connection that has been setup in Arduino besides that, the value of brightness, intensity value and voltage value will be show in numeric indicator. Testing LabVIEW also is took over several condition which are:

- intensity increase or decrease will show in graph lux meter from range 0 to 100

- brightness of led will show in indicator from 0 to 100 percent

- voltage out use from led bulb will show in voltage graph from range $0 \mathrm{v}$ to $12 \mathrm{v}$

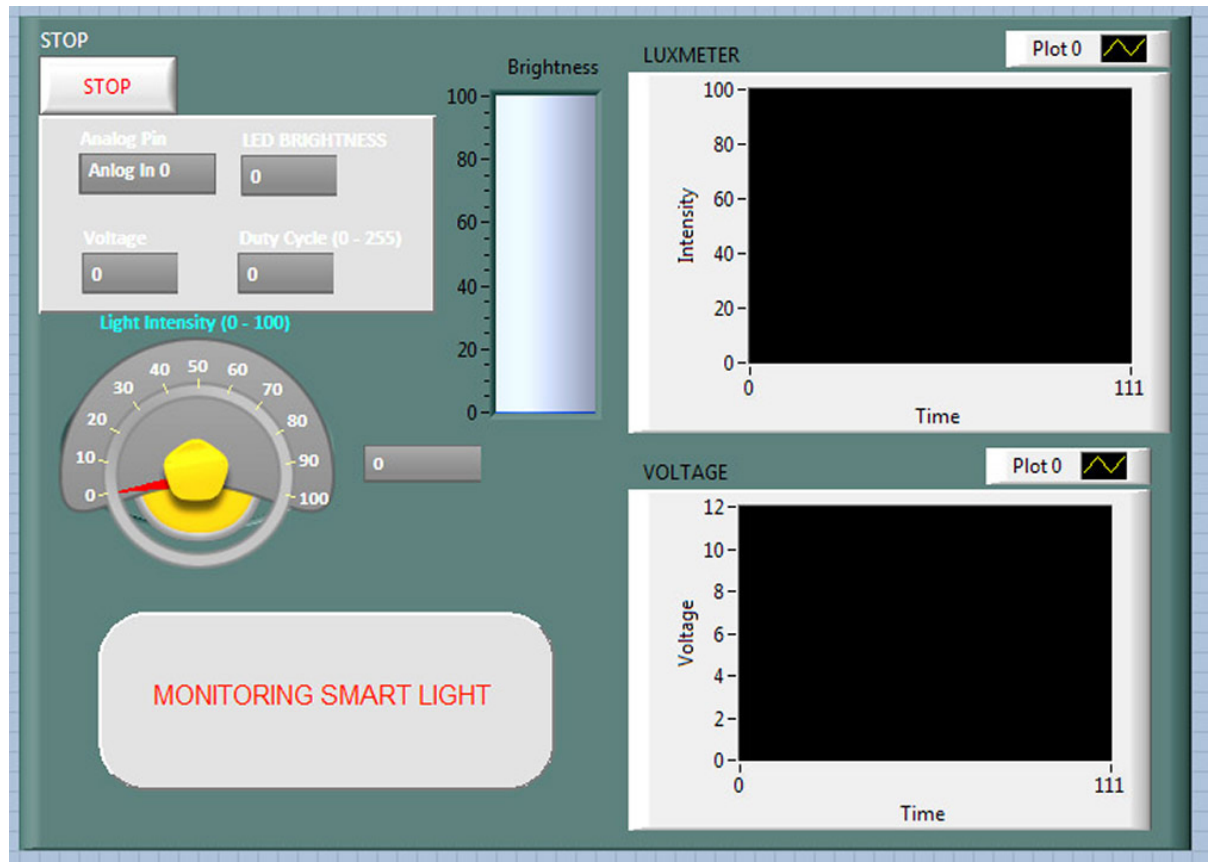

Fig. 6. The graphical user interface (GUI) 


\subsection{Results of intensity and voltage}

Figure 7 shows the relationship between intensity and voltage with time. This experiment conducted in night mode from 5.30 PM until 12.00 AM. Based on that result, the observation of the intensity value will be decreased when no light surrounded in that area and the voltage will be increased with brightness of LED. While, Figure 8 shows the daylight graph that shows intensity and voltage with time. This experiment was began from 3.00 AM to 9.30 AM on that day. Based on the result, the observation of the intensity value will be increased when sensor perceived light in the surrounded area and the voltage will be decreased as followed as by the intensity value and the LED brightness. These two graphs showed how the intensity balanced with the voltage out from the LED lamp.

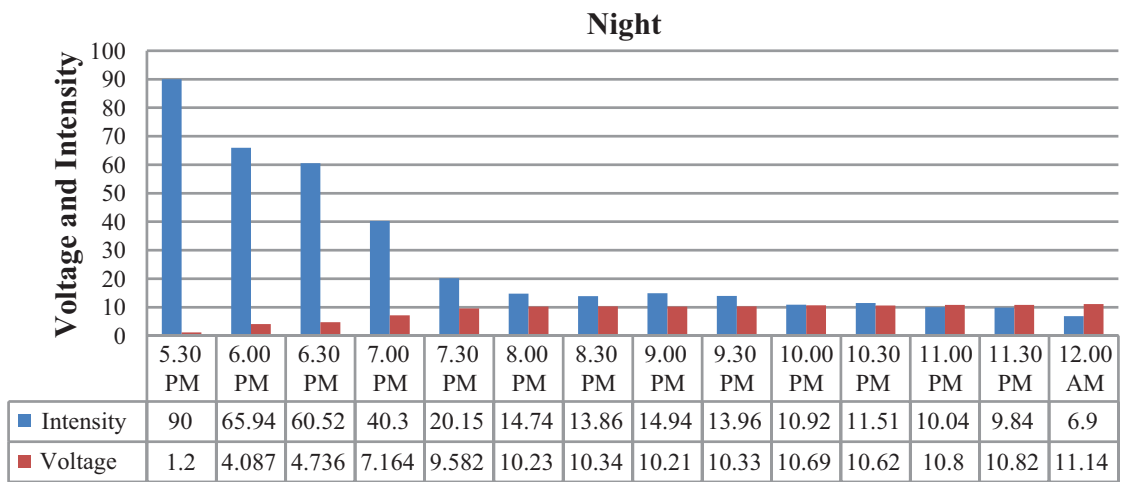

Fig. 7. The observation between intensity and voltage with time - Night

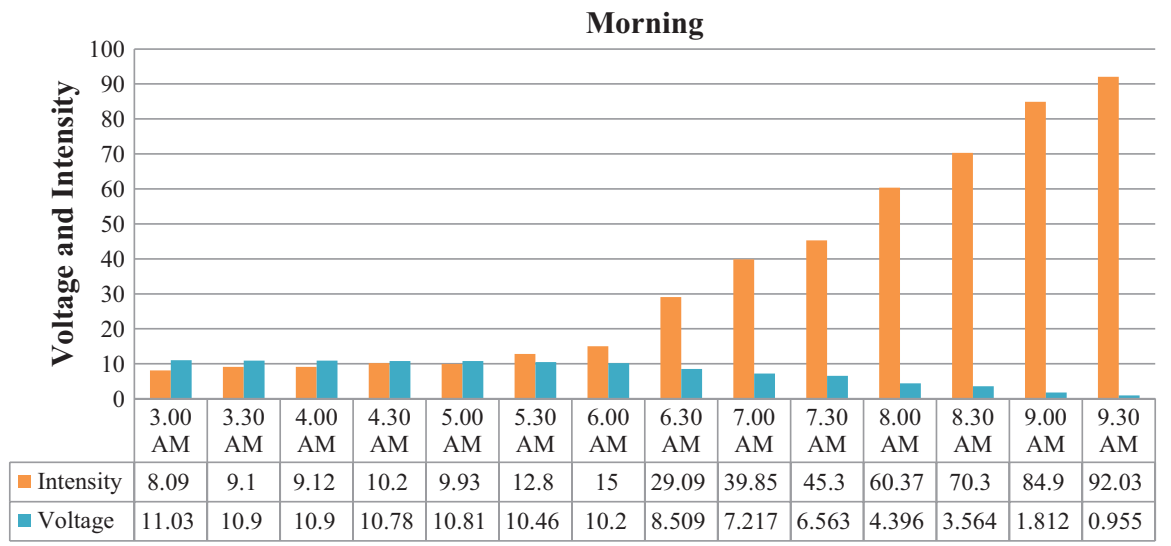

Fig. 8. The observation between intensity and voltage with time - Morning 
The LDR gives out an analog voltage when connected to Vcc (5V), which varies in magnitude in direct proportion to the input light intensity on it. That is, the greater the intensity of light, the greater the corresponding voltage from the LDR will be. Since the LDR gives out an analog voltage, it is connected to the analog input pin on the Arduino. The Arduino converts the analog voltage (from $0-5 \mathrm{~V}$ ) into a digital value in the range of (0-1023). According to the auto mode programing, the timing and the reading it smooth and less noise. The Bluetooth system function perfectly and less error so the user can manually control smooth the Smart Light. By using the user-friendly system via graphical user interface (GUI), user is totally monitoring the electric consumption that out from the smart light. User is easy to adjust the brightness LED using apps thru android follow the user needed.

\section{Conclusion}

A usage of energy consumption increases every year because of demand and usage by human. This research aim to design and develop a smart light system for monitoring and controlling. The development of energy saving smart light system that control light brightness with LDR (Light Dependent Resistor) sensor and occupancy sensor such as PIR (Passive Infrared) sensor is designed and examined. By this research project, lighting system will perform and improve their functioning and ability. The key of this prototype is a light sensor can control light brightness for the system. Therefore, this prototype also using motion sensor to sense movement to increase the light brightness. There are many advantages for this prototype. One of them is the LDR sensor that will control the power of light brightness by intensity. The other advantage is that, the prototype is using LED bulb since it has more life span than other light bulbs and LED uses less power (watts) per unit of light generated (lumens). LED also helps to reduce $\mathrm{CO} 2$ (carbon dioxide) emission and reduce electric bills. The LED is ideal for operation under cold and low outdoor temperature settings. Since mobile phone is an important device/gadget to human kind this project is develop a personal control. Plus, user can connect to Wi-Fi or Bluetooth and control the light using mobile application through LabVIEW graphical user interface monitoring system. This project also may diminish the opportunity of the careless usage of light appliance by human. This will be contributed to the better light system in our life. The functionality of this project also has been examined through the prototype development and the results obtained are validated in order to ensure the goal is achieved.

For future this system is suggested to use the web control and Wi-Fi module for better performance. The data can be save in the website and user can monitor through the computer and devices. Besides that, the connection of the range will be broader that Bluetooth by using the wireless. In a nutshell, it is really great if this technology is improve for experimenting at wide scope in building such as in city of Kuala Lumpur with many buildings and structures.

\section{Acknowledgement}

This work is supported by the Research and Innovation, Universiti Kuala Lumpur. 


\section{$7 \quad$ References}

[1] A. S. Bujang, C. J. Bern and T. J. Brumm (2016) Summary of energy demand and renewable energy policies in Malaysia. Renewable and Sustainable Energy Reviews, 53(2016), 1459-1467. https://doi.org/10.1016/j.rser.2015.09.047

[2] W. Syakirah, W. Abdullah, M. Osman, M. Z. Abidin, A. B. Kadir and R. Verayiah (2019) The potential and status of renewable energy development in Malaysia. Energies, 12(2437), 1-16. https://doi.org/10.3390/en12122437

[3] A. Khamis, A. Alamshah and A. Ahmad (2010) Power Engineering and Optimization Conference (PEOCO), 2010 4th International. Energy \& electricity consumption analysis of Malaysian power demand. Retrieve from http://ieeexplore.ieee.org/document/5559171/; https://doi.org/10.1109/PEOCO.2010.5559171

[4] Christopher The Boon Sung (2010) Electricity demand, economic growth, and sustainable energy resources in Malaysia. Retrieve from http://www.christopherteh.com/blog/2010/09/ electricity-demand/

[5] C. S. Tan, K. Maragatham and Y. P. Leong (2013) Electricity energy outlook in Malaysia. Earth and Environmental Science, 16, 1-4. https://doi.org/10.1088/1755-1315/16/1/012126

[6] Energy Commission (2016). National energy balance 2016. ST(P)01/03/2014 ed.; 2016.

[7] A. Dolaro, M. Longo and M. Cristina (2014) 3rd International Conference on Renewable Energy Research and Applications. Case study of Lights Energy Saving, 19-22. https://doi.org/10.1109/ICRERA.2014.7016543

[8] A. Welhenge (2014) Lighting Control System for Energy saving, 8th Asia Modelling Symposium, 53. https://doi.org/10.1109/AMS.2014.21

[9] A. Masleka, K. Aparna, K. Mamatha and T. Shivakurama (2015) Smart lighting system using raspberry PI. International Journal of Innovative Research in Science, Engineering and Technology, 4(7), 5113-5121. https://doi.org/10.15680/IJIRSET.2015.0407011

[10] A. A. Azlina, M. Kamaludin, Z. E. Siti Abdullah and A. Radam (2016) Factors influencing household end-use electricity demand in Malaysia. Advanced Science Letters, 22(12), 4120-4123. https://doi.org/10.1166/asl.2016.8189

[11] D. K. Rath (2016) Arduino based: Smart light control system. International Journal of Engineering Research and General Science, 4(2), 784-790.

[12] M. Kumar, R. Kumar and R. Thakur (2016) Zigbee based smart street light control system using LabVIEW. International Journal of Innovative Research in Science, Engineering and Technology, 5(4), 5340-5346.

[13] M. Srikanth and K. N. Sudhakar (2014) Zigbee based remote control automatic street light system. International Journal of Engineering Science and Computing, 639-643.

[14] S. P. Deo and A. S. Patil (2014) Zigbee-based intelligent street lighting system. 2nd International Conference on Devices, Circuits and Systems (ICDCS), Combiatore, India, 1-4. https://doi.org/10.1109/ICDCSyst.2014.6926165

[15] P. Elejoste, I. Angulo, A. Perallos, A. Chertudi, I. Julio and G. Zuazola (2013) An easy to deploy street light control system based on wireless communication and LED technology. Sensors International Conference on Ubiquitous Computing and Ambient Intelligence, Basel, 13(5), 6492-6523. https://doi.org/10.3390/s130506492

[16] B. Zirawani, S. A. Sabudin, M. M. Ernie, Yusof, R. Kassim, H. A. M. Noor and H. Mahdin (2020) Energy saving smart light system development: The approach and technique. International Journal of Advanced Trends in Computer Science and Engineering, 9(1.4), 439-449. https://doi.org/10.30534/ijatcse/2020/6291.42020

[17] L. Fabio (2013) Remote-control system of high efficiency and intelligent street lighting using a ZigBee network of devices and sensors. Power Delivery, IEEE Transactions on. 28, 21-28. https://doi.org/10.1109/TPWRD.2012.2212215 
[18] N. Khan, M. Qureshi, I. Mustapha, S. Irum and R. Arshad (2020) A systematic literature review paper on online medical mobile applications in Malaysia. International Journal of Online and Biomedical Engineering, 16(1), 63-82. https://doi.org/10.3991/ijoe.v16i01.12263

[19] M. I. Qureshi, N. Khan, H. Raza, A. Imran and F. Ismail (2021) Digital technologies in education 4.0. Does it enhance the effectiveness of learning? A systematic literature review. International Journal of Interactive Mobile Technologies, 15(4). https://doi.org/10.3991/ ijim.v15i04.20291

[20] I. Mustapha, N. T. Van, M. Shahverdi, M. I. Qureshi and N. Khan (2021) Effectiveness of digital technology in Education during COVID-19 pandemic. A bibliometric analysis. International Journal of Interactive Mobile Technologies, 15(8). https://doi.org/10.3991/ ijim.v15i08.20415

\section{Authors}

Zirawani Baharum, Technical Foundation, Malaysian Institute of Industrial Technology, Universiti Kuala Lumpur, Persiaran Sinaran Ilmu, Bandar Seri Alam, 81750 Johor Bahru. E-mail: zirawani@unikl.edu.my.

Azim Saiful Sabudin, Instrumentation and Control Engineering, Malaysian Institute of Industrial Technology, Universiti Kuala Lumpur, Persiaran Sinaran Ilmu, Bandar Seri Alam, 81750 Johor Bahru.

Ernie Mazuin Mohd Yusof, Instrumentation and Control Engineering, Malaysian Institute of Industrial Technology, Universiti Kuala Lumpur, Persiaran Sinaran Ilmu, Bandar Seri Alam, 81750 Johor Bahru. E-mail: erniemazuin@unikl.edu.my.

Nahdatul Akma Ahmad, Computing Department, Faculty of Communication, Visual Art and Computing, Universiti Selangor, 45600 Bestari Jaya, Selangor, Malaysia. E-mail: nahdatul@unisel.edu.my.

Article submitted 2021-06-11. Resubmitted 2021-07-25. Final acceptance 2021-07-26. Final version published as submitted by the authors. 